Institute of $\mathbf{F}_{\text {ood and }} \mathbf{A}_{\text {gricultural }} \mathbf{S}_{\text {ciences }}$

\title{
West Indian Subterranean Termite, Heterotermes sp. (Insecta: Isoptera: Rhinotermitidae) ${ }^{1}$
}

Rudolf H. Scheffrahn and Nan-Yao Su²

\section{Introduction}

Heterotermes is a structure-infesting termite genus that accounts for a significant proportion of the damage attributed to subterranean termites wherever it occurs. Three species have been reported from the West Indies including $H$. cardini (Snyder), $H$. convexinotatus (Snyder), and H. tenuis (Hagen). Insufficient descriptions, poor museum specimens, and lack of diagnostic characters place the identity of these species in doubt and underscore the need for a taxonomic revision of the genus. Therefore, we have not assigned species names to any Heterotermes from the West Indies nor to the species discovered in Florida. General information related to the life history, damage, and management of Reticulitermes is applicable to Heterotermes and can be obtained from our sister publication on Reticulitermes. This report highlights important distinguishing characteristics of Heterotermes.

\section{Distribution}

Heterotermes is endemic to most of the world's tropics and all of tropical America. This genus has been recorded from almost every island in the Bahamas and West Indies but, strangely, is not endemic to Florida. One exceptional species, $H$. aureus (Snyder), is distributed throughout the lower deserts of northwestern Mexico, southern California, and southern Arizona.

In 1995, a species of Heterotermes was collected from a house in Miami, Florida. This was the first record of Heterotermes in the eastern United States. It has subsequently been collected from two other residential locations and two warehouses in the same Miami neighborhood. One infestation is only one-half mile from Biscayne Bay. Because of its similarity to Heterotermes collected in the West Indies, the predominantly West Indian migrant population of the neighborhood, and proximity to the coast, there is little doubt that these termites were accidentally introduced from the West Indies. As with Coptotermes, Heterotermes can infest boats. In 1995, a boat docked in Grand Cayman Island contained a thriving on-board infestation of Heterotermes.

1. This document is EENY-127 one of a series of Featured Creatures from the Entomology and Nematology Department, Florida Cooperative Extension Service, Institute of Food and Agricultural Sciences, University of Florida. Published: April 2000. This document is also available on Featured Creatures Website at http://creatures.ifas.ufl.edu. Please visit the EDIS Website at http://edis.ifas.ufl.edu. Additional information on these organisms, including many color photographs, is available at the Entomology and Nematology Department website at http://entnemdept.ifas.ufl.edu/.

2. Rudolf H. Scheffrahn, professor and Nan-Yao Su, professor, Entomology and Nematology Department, Ft. Lauderdale REC, University of Florida, Ft. Lauderdale, FL.

The Institute of Food and Agricultural Sciences is an equal opportunity/affirmative action employer authorized to provide research, educational information and other services only to individuals and institutions that function without regard to race, color, sex, age, handicap, or national origin. For information on obtaining other extension publications, contact your county Cooperative Extension Service office. Florida Cooperative Extension Service/Institute of Food and Agricultural Sciences/University of Florida/Christine Taylor Waddill, Dean. 
Miami is the only known locality in tropical America where both Reticulitermes and Heterotermes coincide. Elsewhere in the world, these two widely distributed genera are geographically isolated. Reticulitermes usually inhabits subtropical to cold temperate climates, while Heterotermes, with the exception of a few species, is its tropical counterpart.

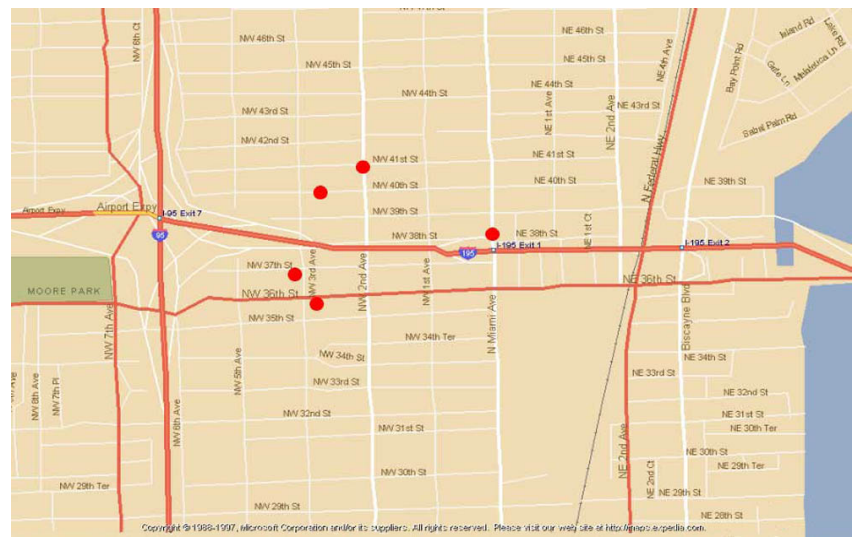

Figure 1. Heterotermes subterranean termite infestation sites in Miami, Florida. Credits: Rudolf H. Scheffrahn, University of Florida

\section{Description and Identification}

Superficially, soldiers of Heterotermes resemble those of Reticulitermes. When viewed from above, both genera have rectangular-shaped heads and no obvious distinguishing features except that the soldiers of Heterotermes are smaller than those of Reticulitermes. Microscopic examination of the mandibles reveals diagnostic differences. The mandibles of Heterotermes soldiers are slender and slightly curved near the tip, while the mandibles of Reticulitermes soldiers are thicker and curved at both their bases and tips. This configuration allows Heterotermes soldiers to cross both mandibles when closed. Reticulitermes can barely overlap the tips of their mandibles when fully closed. Heterotermes soldiers tend to be more aggressive when provoked and constitute a larger proportion of the termite colony than soldiers of Reticulitermes species.

The alates of Heterotermes are about the same size as those of Reticulitermes flavipes (total length with wings about 9-10 $\mathrm{mm}$ ). When compared to body size, the wings of Heterotermes are proportionally longer than the wings of Reticulitermes species. The upper body surfaces of Heterotermes alates are pale yellow-brown to orange-brown, while those of $R$.

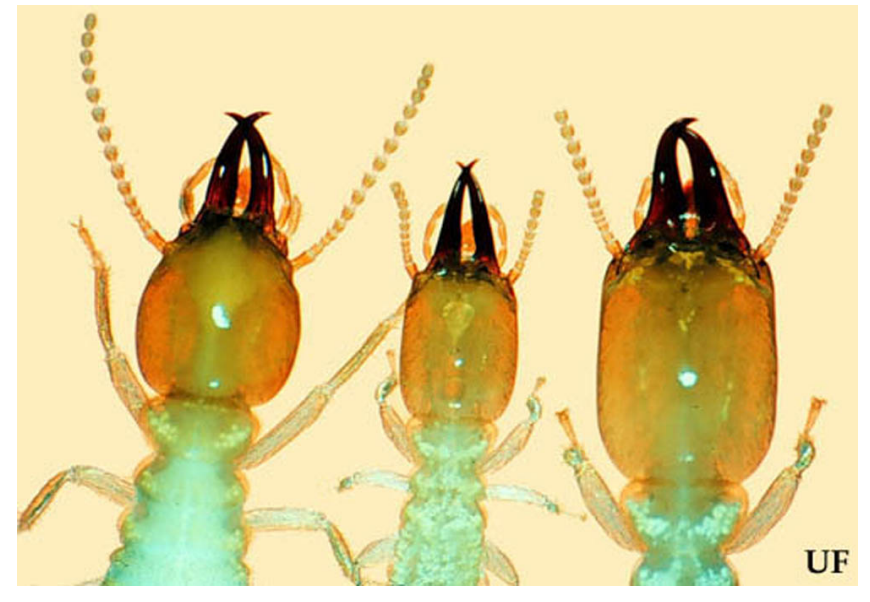

Figure 2. Dorsal views of subterranean termite soldiers. Coptotermes formosanus (left), Heterotermes (center), and Reticulitermes flavipes (right), all from Dade County, Florida. Credits: Rudolf H. Scheffrahn, University of Florida

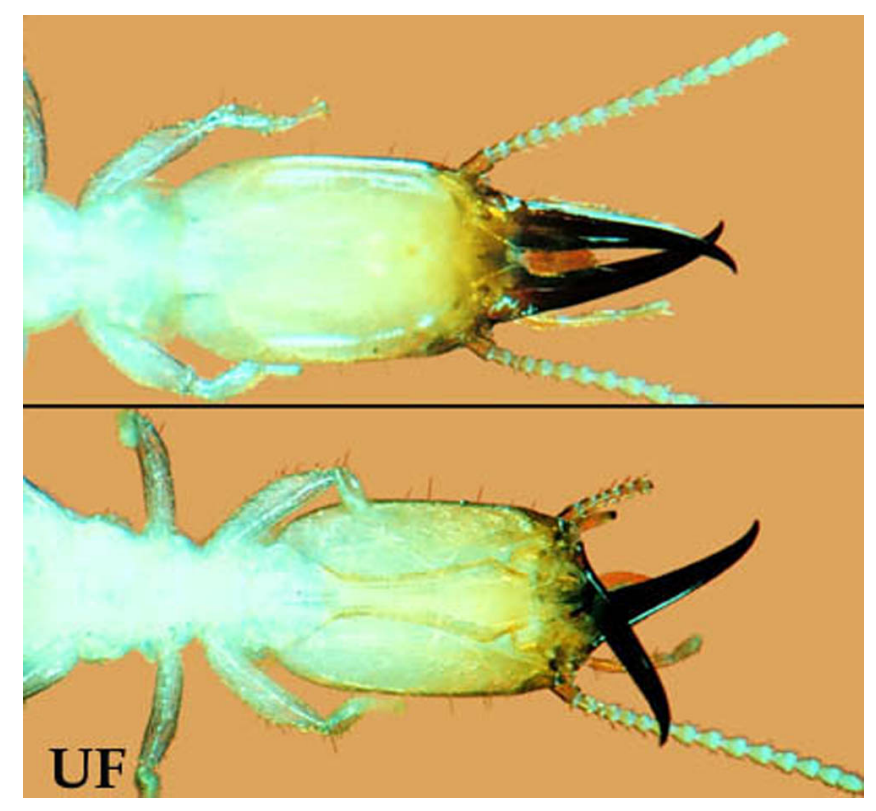

Figure 3. Heterotermes subterranean termite soldier with mandibles in resting position (top) and fully closed (bottom). Credits: Rudolf H. Scheffrahn, University of Florida

flavipes and $R$. virginicus are dark brown to black. The bodies of $R$. hageni are brown. Aside from body color, the wing characters of Heterotermes are useful to distinguish them from Reticulitermes. In Heterotermes, the wing texture is smooth, the membrane surface opaque and yellow-brown, and the margin fringed with tiny hairs. In Reticulitermes, the wing texture is creased with vein-like patterns, the membrane clear, and the margin without hairs. 


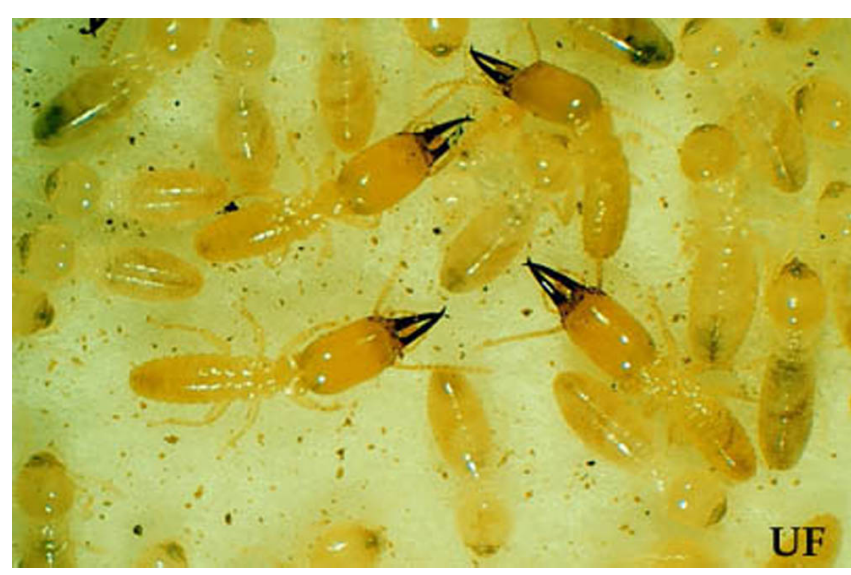

Figure 4. Heterotermes subterranean termite soldiers and workers. Credits: Rudolf H. Scheffrahn, University of Florida

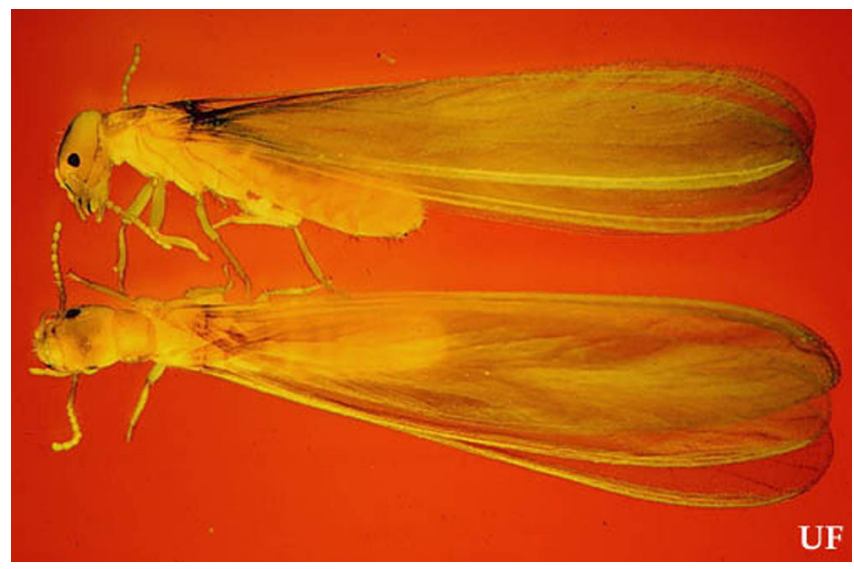

Figure 5. Heterotermes subterranean termite alates in lateral (top) and dorsal views. Credits: Rudolf $\mathrm{H}$.

Scheffrahn, University of Florida

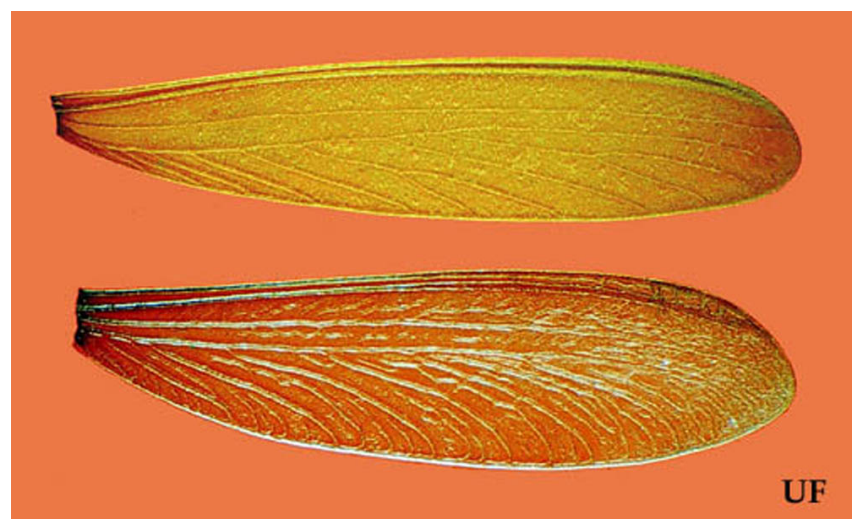

Figure 6. Right fore wing of Heterotermes (top) and Reticulitermes alates (bottom), subterranean termites. Credits: Rudolf H. Scheffrahn, University of Florida

\section{Life History}

Heterotermes and Reticulitermes live in diffuse nests in the soil and share many similarities in colony development and behavior. Some studies suggest that Heterotermes colonies have smaller foraging

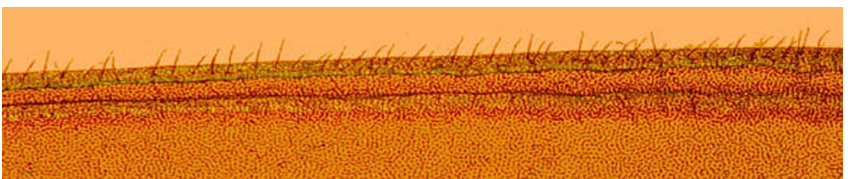

Figure 7. Close-up of Heterotermes subterranean termite wing margin showing microscopic hairs. Credits: Rudolf $\mathrm{H}$. Scheffrahn, University of Florida

territories but greater colony density per given area than those of Reticulitermes. Heterotermes dispersal flights occur at dusk or at night when the rainy season commences in May or June. Occasional smaller flights can occur from August through November. Rainfall usually precedes flight activity. Before flights, alates congregate in "staging" areas near the soil surface or in wood galleries above ground.

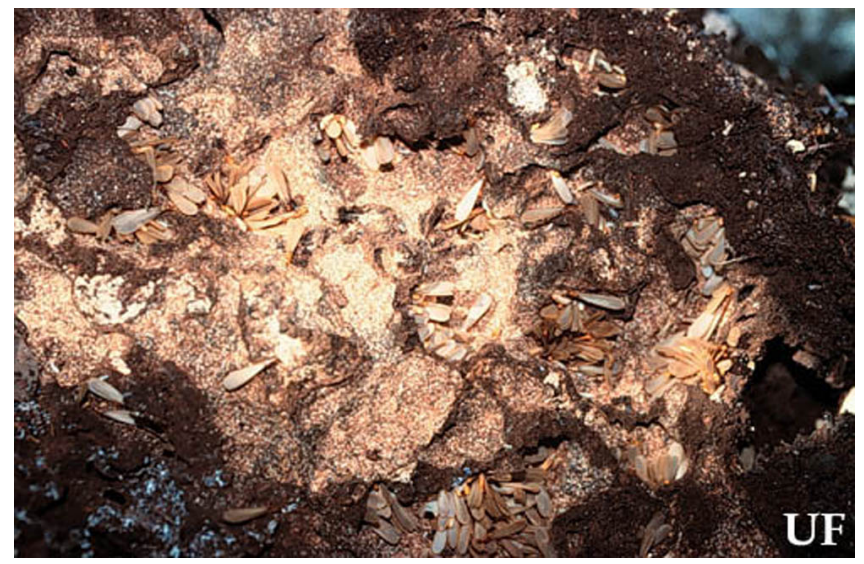

Figure 8. Heterotermes subterranean termite alates congregating beneath a rock before swarm. Credits: Rudolf H. Scheffrahn, University of Florida

\section{Damage}

Like Reticulitermes, damage resulting from a Heterotermes infestation can become severe if left untreated. Subtle differences in foraging behavior and biology, however, do exist. Heterotermes seems to be better adapted to dry environments than Reticulitermes. Heterotermes often forage into wood members that are distant from moisture sources and workers transport little or no free water to feeding sites. Even driftwood lying on dry, hot, and sandy beaches is prone to attack by Heterotermes. Dispersal flights, foraging tubes, or damage (often shredded and dry in appearance) are usually the first indications of an infestation. Heterotermes foraging tubes are lighter in color, narrower, and more circular in cross-section than those of Reticulitermes or Coptotermes. Like their foraging tubes, the 
accumulation of fecal spotting on the surface of Heterotermes-infested wood is also a beige or cream color. In structural infestations, Heterotermes will sometimes openly build very narrow free-hanging tubes from ceilings, shelves, and overhangs.

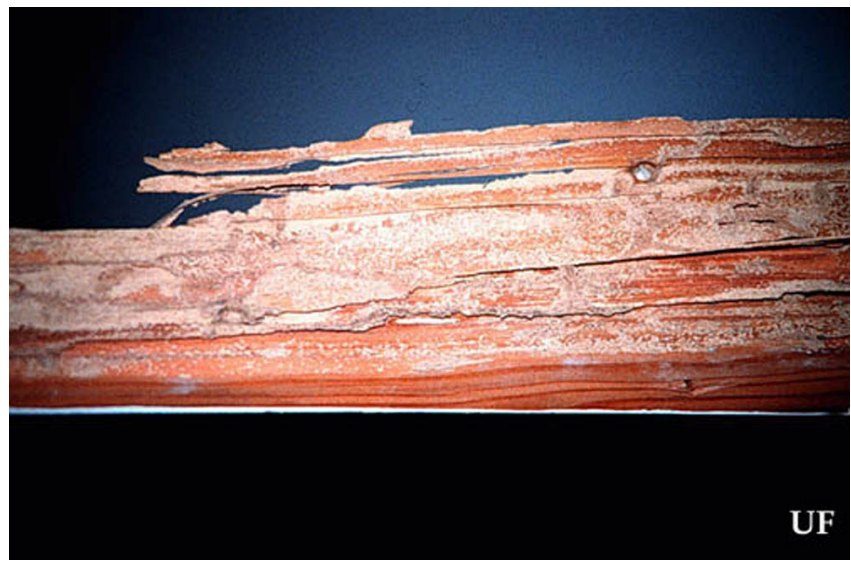

Figure 9. Damage and fecal spotting by Heterotermes subterranean termites to wood molding, Miami, Florida.

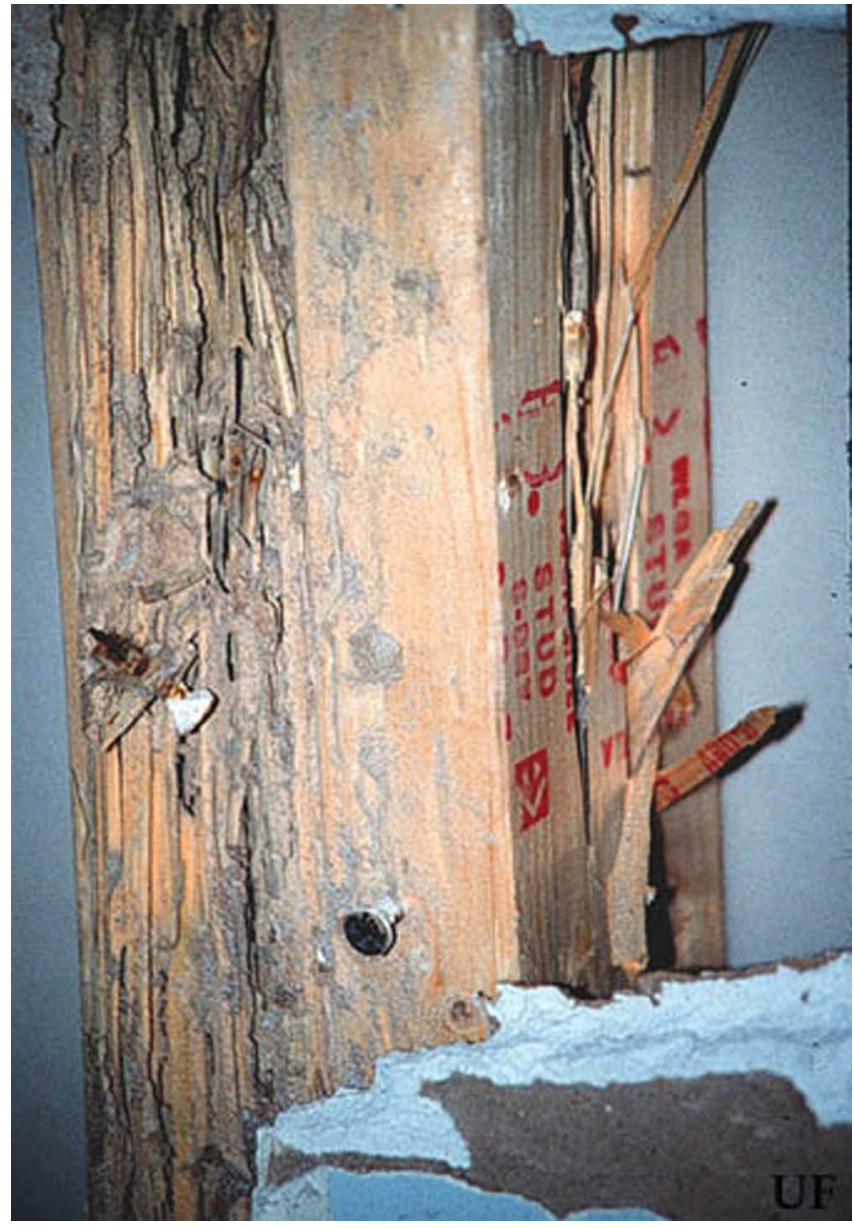

Figure 10. Damage and fecal spotting by Heterotermes subterranean termites in dry framing, Miami, Florida. Credits: Rudolf $\mathrm{H}$. Scheffrahn, University of Florida

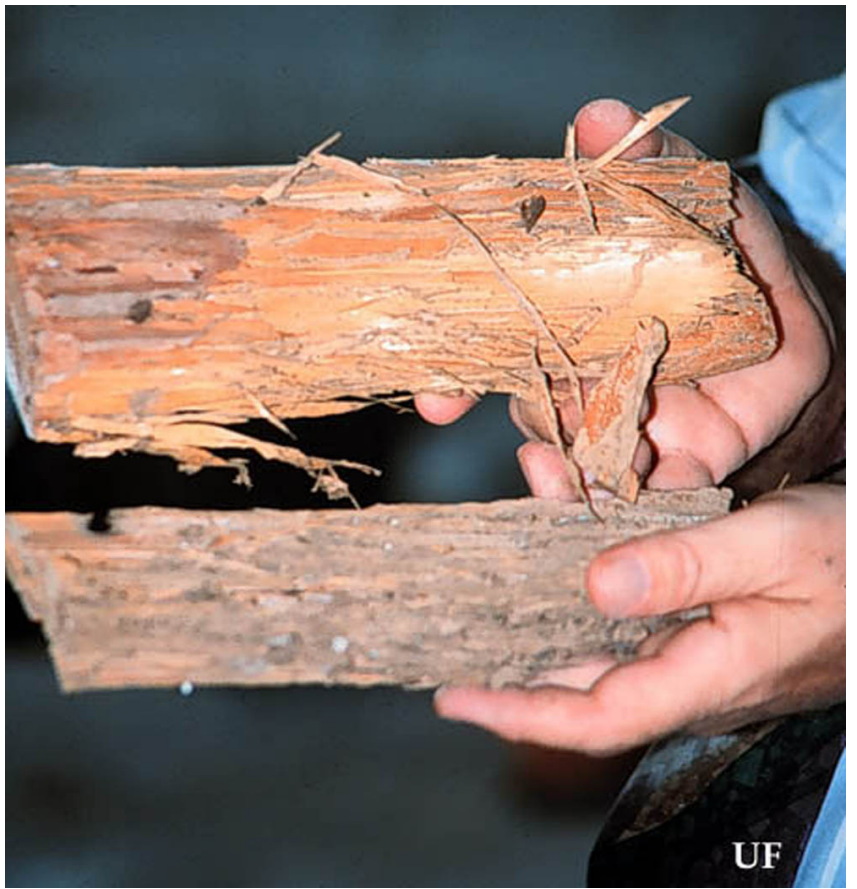

Figure 11. Heterotermes subterranean termite damage showing dry and shredded appearance of wood, Miami, Florida. Credits: Rudolf H. Scheffrahn, University of Florida

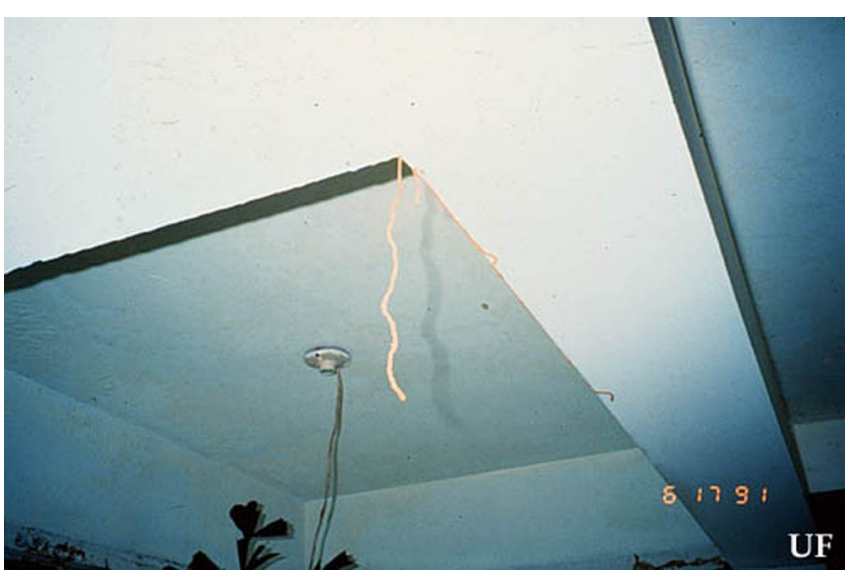

Figure 12. Heterotermes subterranean termite foraging tube dropping from living room ceiling, Santo Domingo, Dominican Republic. Credits: Rudolf H. Scheffrahn, University of Florida

\section{Pest Status}

Infestations of Heterotermes in Miami are infrequent at this time. Having demonstrated successful establishment in Florida suggests that this pest will become more widespread over time. Due to climatic restrictions, the future distribution of Heterotermes in the eastern United States will not likely extend far beyond southern Florida. 


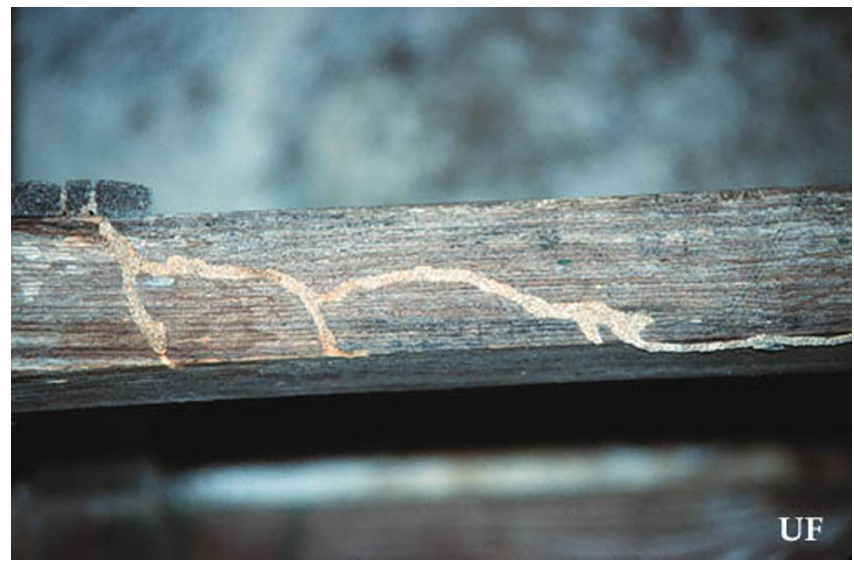

Figure 13. Heterotermes subterranean termite foraging tube on a sheltered bench, Cat Island, Bahamas. Credits: Rudolf $\mathrm{H}$. Scheffrahn, University of Florida

\section{Management}

The same management strategies employed for Reticulitermes should be considered for Heterotermes. Preliminary research suggests that baiting for Heterotermes requires more time than for Reticulitermes or Coptotermes. Given the small size of Heterotermes soldiers and workers, they are apt to penetrate smaller cracks in concrete and masonry that are too narrow for foragers of other subterranean termites to enter.

\section{Selected References}

Jones, S.C. 1990. Delineation of Heterotermes aureus (Isoptera: Rhinotermitidae) foraging territories in a Sonoran desert grassland. Environ. Entomol. 19: 1047-1054.

Scheffrahn, R.H., and N.-Y. Su. 1995. A new subterranean termite introduced to Florida: Heterotermes Froggatt (Rhinotermitidae: Heterotermitinae) established in Miami. Florida Entomol. 78: 623-627. 